\title{
WYBRANE DOCHODY BUDŻETÓW GMIN PRZEKAZYWANE Z BUDŻETU PAŃSTWA W UKŁADZIE PRZESTRZENNYM W POLSCE W LATACH 2004-2011
}

\section{Wprowadzenie}

Przystąpienie Polski do Unii Europejskiej oraz objęcie Polski polityką spójności w okresach programowania 2004-2006 oraz 2007-2013 wyzwoliło głębokie i różnokierunkowe zmiany społeczno-gospodarcze. Zmiany te zarysowały się szczególnie wyraźnie $\mathrm{w}$ ujęciu regionalnym i lokalnym. Istotną rolę $\mathrm{w}$ tym procesie odgrywają jednostki organizacyjne sektora publicznego, które w sposób naturalny stały się beneficjentami wsparcia ze strony Unii Europejskiej w ramach polityki spójności. Odnotowano wyraźny wzrost znaczenia jednostek samorządu terytorialnego stopnia podstawowego, a także podniesienie rangi regionu jako jednostki przestrzennej oraz ekonomiczno-administracyjnej w procesach rozwoju społeczno-gospodarczego. Jednocześnie rozwój społeczno-gospodarczy po roku 2004 odbywał się w warunkach występowania dość znacznych dysproporcji w ujęciu przestrzennym. Dysproporcje te występowały w różnych dziedzinach i już wówczas były przedmiotem ukierunkowanych, konsekwentnych działań, co miało prowadzić do ograniczenia negatywnych skutków nadmiernego zróżnicowania przestrzennego. Należy przy tym podkreślić, że planowany rozwój regionalny i lokalny oraz spodziewana poprawa warunków życia mieszkańców wiązały się z koniecznością ponoszenia znacznych nakładów inwestycyjnych, głównie w zakresie infrastruktury technicznej i społecznej. Rozwiązanie problemów finansowania inwestycji wymagało łączenia środków z różnych źródeł, zwłaszcza własnych zasobów publicznych oraz zasobów pochodzących z budżetu Unii Europejskiej. Współfinansowanie zadań w takiej formule nadal stanowi dla Polski szansę przeprowadzenia znaczących zmian nie tylko w sferze infrastruktury, a także w strukturze gospodarki.

Współczesne koncepcje rozwoju regionalnego i lokalnego wiele uwagi poświęcają rozwojowi opartemu na czynnikach o charakterze endogenicznym. Oznacza to szerokie wykorzystywanie zasobów własnych na potrzeby inicjowania i wdrażania procesów rozwoju, przy założeniu maksymalnej mobilizacji i optymalizacji 
wykorzystania zasobów na danym terenie, włączając w to kapitał, pracę oraz instytucjonalne zasoby i lokalną infrastrukturę ${ }^{1}$. Podejmowane działania opierają się na założeniu, że lokalne fundusze są efektywniej wykorzystywane niż fundusze centralne w sytuacji ich ukierunkowania na cele rozwoju lokalnej infrastruktury technicznej i społecznej. Założenie to wiąże się z dążeniem do rozwoju na danym obszarze własnych zasobów, rozwijaniem nowych technologii i produktów oraz ogólnym wzrostem jakościowym warunków dla działalności gospodarczej i osadnictwa.

Realizacja postulatu rozwoju opartego na czynnikach endogenicznych dość często utożsamiana jest $\mathrm{z}$ dążeniem do zwiększania możliwości podejmowanie samodzielnych decyzji przez władze samorządowe oraz przekonaniem, że korzystanie ze środków uzyskiwanych w formie dotacji celowych i subwencji pozostawia w znacznym stopniu możliwość wpływu administracji rządowej na zarządzanie zasobami publicznymi, w tym szczególnie zasobami finansowymi, jednostki samorządu terytorialnego. Rozważając znaczenie poszczególnych źródeł dochodów budżetowych w zarządzaniu finansami, należy jednak określić, jaką swobodę mają samorządy nie tylko w zakresie gromadzenia środków budżetowych, ale również ich wydatkowaniu². Dochody przekazywane jednostkom samorządu terytorialnego za pośrednictwem budżetu państwa, mające zatem charakter zewnętrzny, wpisują się jednoznacznie $\mathrm{w}$ instrumentarium polityki rozwoju, mimo ich niewątpliwie ograniczającego charakteru w zakresie samodzielności finansowej tych jednostek. Dochody te pełnią jednocześnie funkcję wsparcia wybranych obszarów problemowych, wymagających szczególnej interwencji i jednocześnie kontroli określonej części gospodarki finansowej samorządu terytorialnego przez instytucje administracji państwowej.

W pracy zaprezentowane zostały wyniki badań dochodów budżetowych gminnych jednostek samorządu terytorialnego w Polsce obejmujące lata 2004-2011. Opracowanie stanowi część szerzej zakrojonych i przeprowadzonych w latach ubiegłych badań obejmujących zmiany w zakresie gospodarki budżetowej jednostek samorządu terytorialnego w Polsce w odniesieniu do dochodów oraz wydatków budżetowych. Z uwagi na ograniczone możliwości prezentacji wyników przedstawiono zmiany w poziomie dochodów gmin $\mathrm{z}$ tytułu udziału w podatkach stanowiących dochody budżetu państwa (PIT i CIT), subwencji oraz dochodów związanych z realizacją programów i projektów unijnych, w podziale na zróżnicowane kategorie dochodów Polsce w latach 2004-2011³. Rozważając problematykę zasilania finansowego budżetów gmin, w badaniu uwzględniono wszystkie kategorie składające się

1 A. Klasik, Zarzadzanie rozwojem lokalnym, w: Zarządzanie rozwojem gminy w zespołach miejsko-przemysłowych, pr. zb. pod red. F. Kuźnika, Wydawnictwo AE w Katowicach, Katowice 1996, s. 16.

2 Szerzej zob. L. Węgrzyn, Samodzielni - niesamodzielni, „Przegląd Komunalny” 2006, nr 6, s. 90.

3 W latach 2011-2012 pracownicy Zakładu Zarządzania w Sektorze Publicznym w Katedrze Samorządu Terytorialnego i Gospodarki Lokalnej - K. Jarosiński i B. Opałka -opracowali temat badawczy „Zarządzanie 
na ogół dochodów budżetowych. Z uwagi na ograniczone możliwości zakres tematyczny przedłożonego opracowania zawężony został do trzech kategorii dochodów przekazywanych do gmin z budżetu państwa, które w znaczącym stopniu wpływają na gospodarkę budżetową gmin w Polsce.

\section{Charakterystyka wybranych dochodów budżetów gmin przekazywanych z budżetu państwa Polsce w latach 2004-2011}

W strukturze dochodów budżetów gmin znaczącą pozycję stanowią strumienie pieniężne przekazywane gminom w postaci udziału w podatkach stanowiących dochody budżetu państwa. Z uwagi na zróżnicowany stopień rozwoju społeczno-gospodarczego pomiędzy regionami w Polsce w latach 2004-2011 odnotowano znaczące dysproporcje w poziomie dochodów z tego tytułu oraz duże zróżnicowanie międzyregionalne pod względem udziału tej kategorii dochodów w dochodach budżetowych ogółem gmin. W całym omawianym okresie najwyższy poziom bezwzględny dochodów odnotowano w województwie mazowieckim. Jeśli w roku 2004 dochody tej kategorii wyniosły 3,78 mld zł, to już w roku 2011 kształtowały się na poziomie $6,46 \mathrm{mld}$ zł. Relatywnie wysoki poziom dochodów regionu mazowieckiego w stosunku do regionów pozostałych wynikał z silnie dodatniego wpływu sytuacji gospodarczej w aglomeracji warszawskiej na pozostałą część regionu.

Relatywnie wysokie dochody odnotowano w omawianym okresie w województwie śląskim. O ile w roku 2004 dochody te wyniosły 2,19 mld zł, o tyle już w roku 2011 kształtowały się na poziomie 3,87 mld zł. Stosunkowo niskie dochody z tytułu udziału w podatkach stanowiących dochody budżetu państwa razem odnotowano $\mathrm{w}$ mniejszych regionach (opolskie, lubuskie), a także w regionach o stosunkowo niskim poziomie rozwoju gospodarczego (podlaskie, świętokrzyskie, warmińsko-mazurskie). W roku 2004, zgodnie z danymi zamieszczonymi w tabeli 1, pomiędzy poszczególnymi regionami w Polsce występowały duże różnice. Jeśli różnica w poziomie dochodów podatkowych w omawianej kategorii podatkowej pomiędzy gminami o najwyższej i najniższej kwocie dochodów w roku 2004 wyniosła 3,44 mld zł (region mazowiecki oraz region lubuski), to już w roku 2011 różnica pomiędzy tymi województwami o skrajnym poziomie dochodów wynosiła 5,92 mld zł (województwo mazowieckie oraz opolskie).

zasobami publicznymi w warunkach gospodarki budżetowej samorządu terytorialnego w Polsce", wchodzący w skład szerszych badań Katedry. 
Tabela 1. Dochody budżetów gmin z tytułu udziału w podatkach stanowiących dochody budżetu państwa razem w układzie regionalnym (w tys. zł)

\begin{tabular}{|l|r|r|r|r|r|r|r|r|}
\hline Wyszczególnienie & \multicolumn{1}{|c|}{2004} & \multicolumn{1}{|c|}{2005} & \multicolumn{1}{c|}{2006} & \multicolumn{1}{c|}{2007} & 2008 & 2009 & \multicolumn{1}{c|}{2010} & 2011 \\
\hline Łódzkie & 872204 & 1013996 & 1168778 & 1458924 & 1620372 & 1539334 & 1529112 & 1674702 \\
\hline Mazowieckie & 3727526 & 4183696 & 4900548 & 6100870 & 6599288 & 6362010 & 6173858 & 6461931 \\
\hline Małopolskie & 1049286 & 1217769 & 1450698 & 1824578 & 2117001 & 1996462 & 1978957 & 2192764 \\
\hline Śląskie & 2186789 & 2523502 & 2841964 & 3480244 & 3809373 & 3443507 & 3466891 & 3870571 \\
\hline Lubelskie & 508937 & 590381 & 692662 & 863516 & 961191 & 871539 & 871497 & 1002289 \\
\hline Podkarpackie & 457509 & 526507 & 619467 & 760445 & 871893 & 779177 & 767590 & 897205 \\
\hline Podlaskie & 306052 & 375010 & 417273 & 528594 & 594794 & 560198 & 539199 & 601654 \\
\hline Świętokrzyskie & 318168 & 353145 & 405775 & 505021 & 584680 & 545406 & 533079 & 604017 \\
\hline Lubuskie & 287275 & 336982 & 395549 & 497664 & 552482 & 501839 & 498412 & 559398 \\
\hline Wielkopolskie & 1249075 & 1444145 & 1667282 & 2064242 & 2288363 & 2208555 & 2173877 & 2373954 \\
\hline Zachodniopomorskie & 530288 & 616349 & 723591 & 923701 & 1022724 & 978257 & 952431 & 1053568 \\
\hline Dolnośląskie & 1062745 & 1257765 & 1466050 & 1875275 & 2096811 & 1996780 & 1979023 & 2170970 \\
\hline Opolskie & 284303 & 349258 & 390071 & 476637 & 537120 & 497960 & 490092 & 541270 \\
\hline Kujawsko-pomorskie & 655861 & 738878 & 864344 & 1074449 & 1202678 & 1125633 & 1096513 & 1226421 \\
\hline Pomorskie & 857200 & 988027 & 1169203 & 1479435 & 1647325 & 1566031 & 1552907 & 1683802 \\
\hline Warmińsko-mazurskie & 372055 & 441584 & 510444 & 640554 & 709570 & 653876 & 637130 & 702845 \\
\hline
\end{tabular}

Źródło: opracowanie własne na podstawie danych Banku Danych Lokalnych, GUS, Warszawa 2012.

Wzrost dochodów budżetowych gmin z tytułu udziału w podatkach stanowiących dochody budżetu państwa razem był uwarunkowany oddziaływaniem czynników o charakterze regulacyjnym, związanym ze zmianami wielkości udziałów, jak również stanowił pochodną zmian w sytuacji dochodowej ludności oraz podmiotów gospodarczych, czego wyrazem był wzrost przepływów związanych z powyższym podatkiem. Wzrost dochodów z tytułu udziału w podatkach stanowiących dochody budżetu państwa razem był zatem odzwierciedleniem zmian zachodzących $\mathrm{w}$ gospodarce i jako taki powinien być oceniany pozytywnie. Nieco inny wymiar ekonomiczny mają jednak powiększające się dysproporcje w poziomie dochodów z tytułu udziałów w tych kategoriach podatków, co w znaczącym stopniu może wpływać na pogłębianie się różnic międzyregionalnych. Mając na uwadze politykę spójności Unii Europejskiej oraz mechanizmy z tym związane, różnice międzyregionalne w zakresie bazy podatkowej mogą wydawać się niepokojące. Graficzną interpretację danych empirycznych dotyczących zmian poziomu omawianych dochodów zaprezentowano na rysunku 1. Szczegółową ilustrację sytuacji w zakresie dochodów gmin z tytułu udziału w podatkach stanowiących dochody budżetu państwa razem w układzie powiatowym przedstawiono na rysunku 2. 
Rysunek 1. Dochody budżetów gmin z tytułu udziału w podatkach stanowiących dochody budżetu państwa razem w układzie regionalnym (w tys. zl)

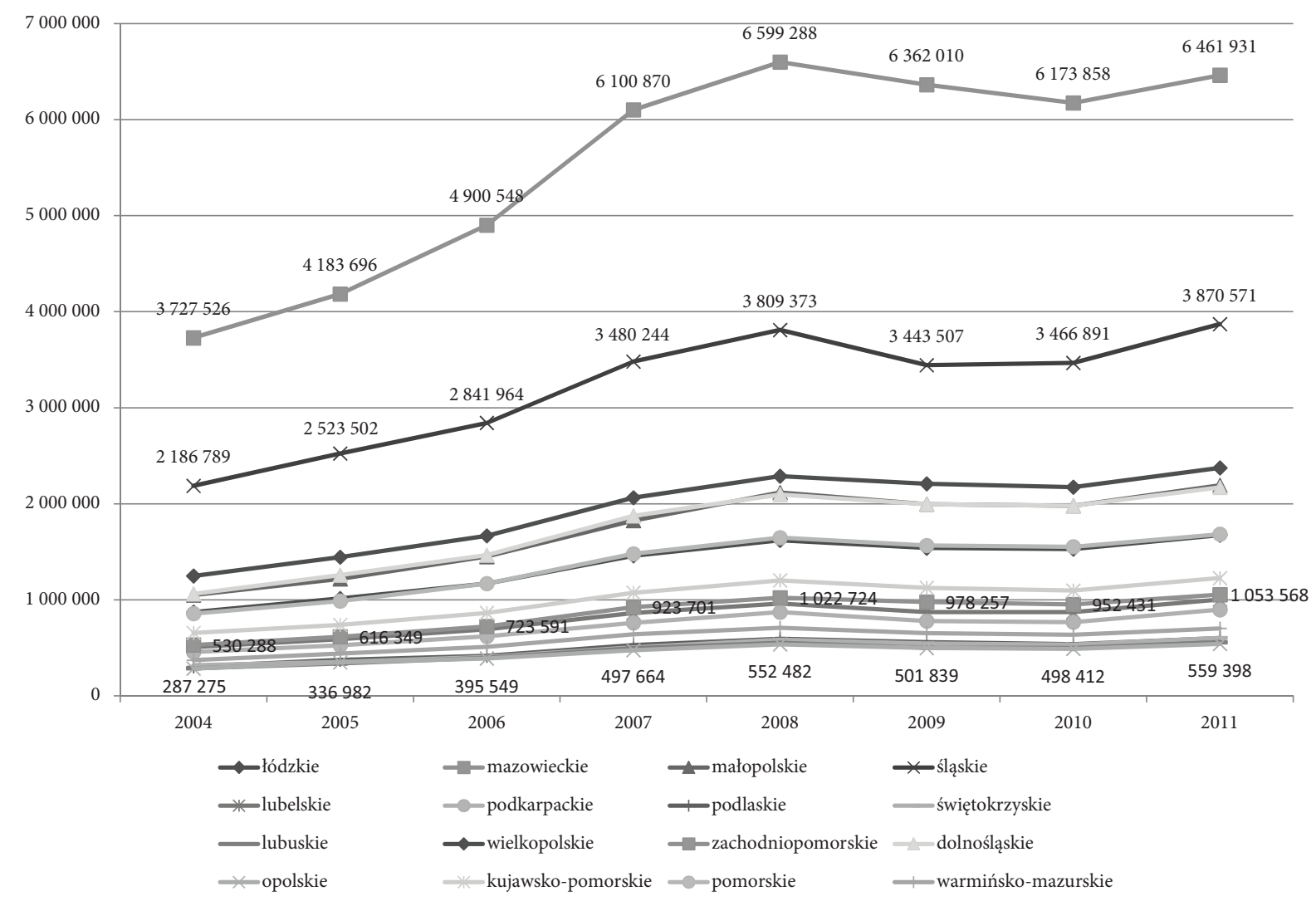

Źródło: K. Jarosiński, B. Opałka, Zarzadzanie zasobami publicznymi w warunkach gospodarki budżetowej samorzadu terytorialnego w Polsce, badanie statutowe, KES, SGH, Warszawa 2012.

Dochodami budżetów gmin z tytułu udziału w podatkach stanowiących dochody budżetu państwa są: udziały w podatku dochodowym od osób fizycznych oraz z tytułu podatku od osób prawnych. Na podstawie danych empirycznych zestawionych $\mathrm{w}$ tabeli 1 oraz tabeli 2 można stwierdzić, że dochody $\mathrm{z}$ tytułu udziału w podatku od osób fizycznych odgrywają ważniejszą rolę w budżetach gminnych. Przykładowo w roku 2004 w regionie łódzkim udział podatków od osób fizycznych w ogólnej kwocie dochodów budżetowych z tytułu podatków stanowiących dochód budżetu państwa kształtował się na poziomie 93,1\%, zaś w roku 2011 na poziomie $92,3 \%$. W regionie mazowieckim tym samym czasie udziały te kształtowały się odpowiednio na poziomie $85,8 \%$ i $88,7 \%$. W regionach słabiej rozwiniętych gospodarczo w roku 2004 udział ten kształtował się na poziomie przekraczającym 90\%. W województwie podkarpackim wyniósł $91,1 \%$, w województwie podlaskim 92,5\%, a w województwie lubelskim - 93,1\%. W 2011 r. zależność dochodowa gmin od tej kategorii podatkowej zwiększyła się i wynosiła odpowiednio: 92,8\%, 95,7\% oraz $94,3 \%$. 
Rysunek 2. Dochody budżetów gmin z tytułu udziału w podatkach stanowiących dochody budżetu państwa razem w układzie powiatowym (w tys. zł)
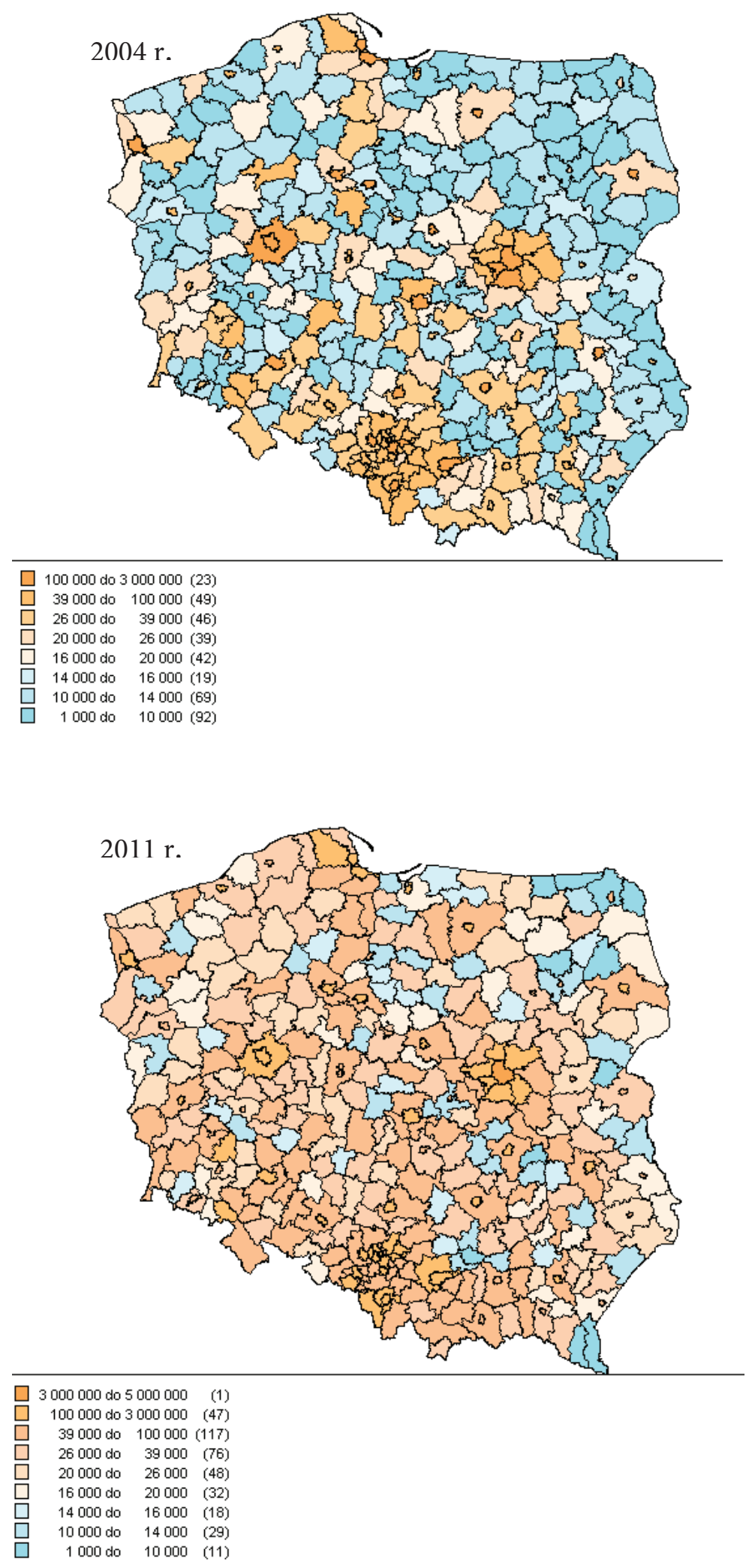

Źródło: K. Jarosiński, B. Opałka, op.cit. 
Tabela 2. Dochody budżetów gmin z tytułu udziału w podatku dochodowym od osób fizycznych w układzie regionalnym (w tys. zł)

\begin{tabular}{|l|r|r|r|r|r|r|r|r|}
\hline Wyszczególnienie & 2004 & 2005 & 2006 & 2007 & 2008 & 2009 & 2010 & 2011 \\
\hline Łódzkie & 811464 & 946350 & 1085908 & 1348872 & 1499025 & 1410163 & 1401205 & 1546748 \\
\hline Mazowieckie & 3197450 & 3606311 & 4181379 & 5202527 & 5649922 & 5550197 & 5492644 & 5729900 \\
\hline Małopolskie & 961528 & 1138763 & 1331917 & 1676803 & 1924499 & 1840606 & 1857049 & 2051172 \\
\hline Śląskie & 1997940 & 2323583 & 2619434 & 3220985 & 3528744 & 3218639 & 3244335 & 3586592 \\
\hline Lubelskie & 473607 & 549250 & 648999 & 800584 & 896005 & 814544 & 825668 & 944715 \\
\hline Podkarpackie & 416572 & 483423 & 574037 & 699999 & 812956 & 721915 & 717515 & 832686 \\
\hline Podlaskie & 283122 & 352222 & 393406 & 493674 & 558916 & 523250 & 510996 & 575891 \\
\hline Świętokrzyskie & 296862 & 329331 & 376041 & 461948 & 528107 & 491608 & 498548 & 562654 \\
\hline Lubuskie & 261770 & 310157 & 365622 & 453739 & 510483 & 468514 & 466948 & 523851 \\
\hline Wielkopolskie & 1117565 & 1304092 & 1502281 & 1859486 & 2067918 & 1997265 & 1971965 & 2165380 \\
\hline Zachodniopomorskie & 498204 & 578301 & 680535 & 861936 & 960430 & 913494 & 900541 & 995411 \\
\hline Dolnośląskie & 962376 & 1120887 & 1318893 & 1669336 & 1876989 & 1808397 & 1798944 & 1944725 \\
\hline Opolskie & 264046 & 304721 & 352517 & 431603 & 488318 & 451028 & 455476 & 506160 \\
\hline Kujawsko-pomorskie & 599233 & 685169 & 801727 & 993540 & 1116017 & 1042866 & 1031743 & 1147074 \\
\hline Pomorskie & 777211 & 914840 & 1060359 & 1348502 & 1504904 & 1450696 & 1436341 & 1551831 \\
\hline Warmińsko-mazurskie & 344162 & 411729 & 482714 & 602933 & 671531 & 619795 & 605300 & 672366 \\
\hline
\end{tabular}

Źródło: K. Jarosiński, B. Opałka, op.cit.

\section{Rysunek 3. Dochody budżetów gmin z tytułu udziału w podatku dochodowym od osób fizycznych w układzie regionalnym (w tys. zl)}

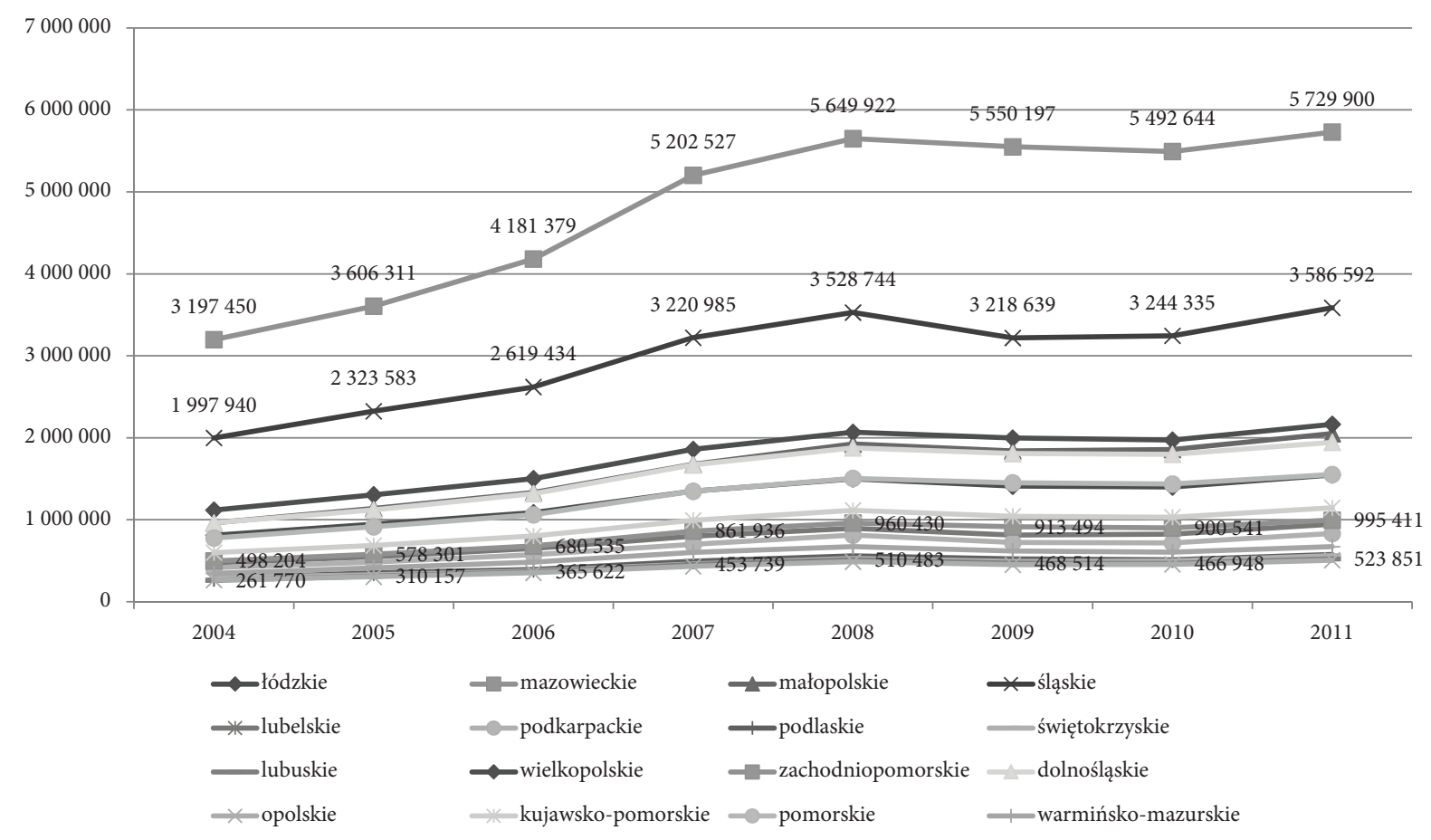

Źródło: K. Jarosiński, B. Opałka, op.cit. 
Na tle przedstawionych rozważań istotne znaczenie ma analiza udziału dochodów z tytułu udziału w podatku dochodowym od osób fizycznych w dochodach ogółem budżetów gmin w układzie regionalnym. Szczegółowe dane dotyczące tego zagadnienia zamieszczono w tabeli 3. W roku 2004 najwyższym udziałem charakteryzowało się województwo mazowieckie $-26,7 \%$. Udział ten w całym omawianym okresie utrzymywał się na zbliżonym poziomie, osiągając najwyższą wartość w roku 2008, tj. 28,6\%. Również wysoki poziom omawianego wskaźnika odnotowano w województwie śląskim, gdzie wyniósł on w 2004 r. 21,4\%, osiągając najwyższy poziom - 25,7\% - w roku 2008. Najniższy poziom wskaźnika w roku 2004 odnotowano w województwie podkarpackim - 12,1\%, niskie wartości występowały także w województwach lubelskim i warmińsko-mazurskim.

Tabela 3. Udział dochodów z tytułu udziału w podatku dochodowym od osób fizycznych w dochodach ogółem budżetów gmin w układzie regionalnym (w \%)

\begin{tabular}{|l|c|c|c|c|c|c|c|c|}
\hline \multicolumn{1}{|c|}{ Wyszczególnienie } & 2004 & 2005 & 2006 & 2007 & 2008 & 2009 & 2010 & 2011 \\
\hline Łódzkie & 17,7 & 18,7 & 19,0 & 21,4 & 21,5 & 19,3 & 18,1 & 19,1 \\
\hline Mazowieckie & 26,7 & 25,5 & 25,3 & 28,1 & 28,6 & 27,9 & 26,0 & 25,4 \\
\hline Małopolskie & 16,7 & 17,3 & 17,8 & 19,6 & 20,9 & 18,9 & 17,1 & 18,3 \\
\hline Śląskie & 21,4 & 22,6 & 23,2 & 25,3 & 25,7 & 23,1 & 21,3 & 22,6 \\
\hline Lubelskie & 13,2 & 13,8 & 14,6 & 16,4 & 16,9 & 14,6 & 13,1 & 14,0 \\
\hline Podkarpackie & 12,1 & 12,3 & 12,8 & 14,2 & 15,1 & 12,8 & 10,8 & 12,3 \\
\hline Podlaskie & 13,8 & 14,9 & 14,9 & 17,3 & 17,8 & 14,8 & 13,3 & 14,3 \\
\hline Świętokrzyskie & 14,3 & 14,0 & 13,9 & 16,2 & 16,6 & 14,1 & 12,2 & 13,6 \\
\hline Lubuskie & 14,6 & 14,6 & 16,0 & 17,2 & 19,1 & 16,3 & 15,2 & 16,7 \\
\hline Wielkopolskie & 18,4 & 18,7 & 19,7 & 21,3 & 21,6 & 20,6 & 19,1 & 19,7 \\
\hline Zachodniopomorskie & 15,7 & 15,8 & 16,8 & 19,0 & 19,6 & 18,0 & 17,0 & 17,5 \\
\hline Dolnośląskie & 16,8 & 17,2 & 17,7 & 20,1 & 22,0 & 20,6 & 18,2 & 18,4 \\
\hline Opolskie & 15,3 & 15,4 & 16,0 & 17,6 & 18,8 & 17,1 & 15,7 & 17,0 \\
\hline Kujawsko-pomorskie & 16,0 & 16,1 & 16,8 & 18,5 & 18,9 & 17,3 & 16,0 & 16,9 \\
\hline Pomorskie & 17,4 & 18,3 & 18,4 & 20,4 & 21,7 & 20,8 & 17,9 & 18,5 \\
\hline Warmińsko-mazurskie & 13,4 & 14,1 & 14,7 & 16,6 & 17,1 & 15,4 & 13,5 & 14,0 \\
\hline
\end{tabular}

Źródło: opracowanie własne na podstawie danych Banku Danych Lokalnych, op.cit.

Udział gmin w dochodach podatkowych stanowiących dochody budżetu państwa stanowi jedno z ważniejszych źródeł zasilania finansowego. Udziały te nie tylko są przedmiotem oddziaływania czynników o charakterze ekonomicznym, ale należą też do sfery oddziaływania czynników o charakterze regulacyjnym. Występuje tutaj istotny problem ustalenia zasad podziału dochodów podatkowych $\mathrm{w}$ formie 
podatków: dochodowego od osób fizycznych oraz dochodowego od osób prawnych. Ustalenie zasad podziału stanowi rezultat poszukiwania możliwości wyboru optymalnej ścieżki finansowania zadań na poziomie państwa oraz jednostek samorządu terytorialnego. Konsensus dotyczący struktury podziału wspomnianych dochodów jest swoistą umową społeczną, zgodnie z którą część dochodów wypracowanych na terenie gminy powraca do niej za pomocą systemu redystrybucyjnego państwa.

Ilustrację graficzną udziału dochodów z tytułu podatku dochodowego od osób fizycznych w dochodach ogółem budżetów gmin w układzie przestrzennym regionów przedstawiono na rysunku 4. Charakterystykę udziału dochodów gmin w układzie powiatowym $\mathrm{z}$ tytułu udziału w podatku dochodowym od osób fizycznych w dochodach ogółem budżetów gmin przedstawiono na rysunku 5.

\section{Rysunek 4. Udział dochodów gmin z tytułu udziału w podatku dochodowym od osób fizycznych w dochodach ogółem budżetów gmin w układzie regionalnym ( $w \%)$}

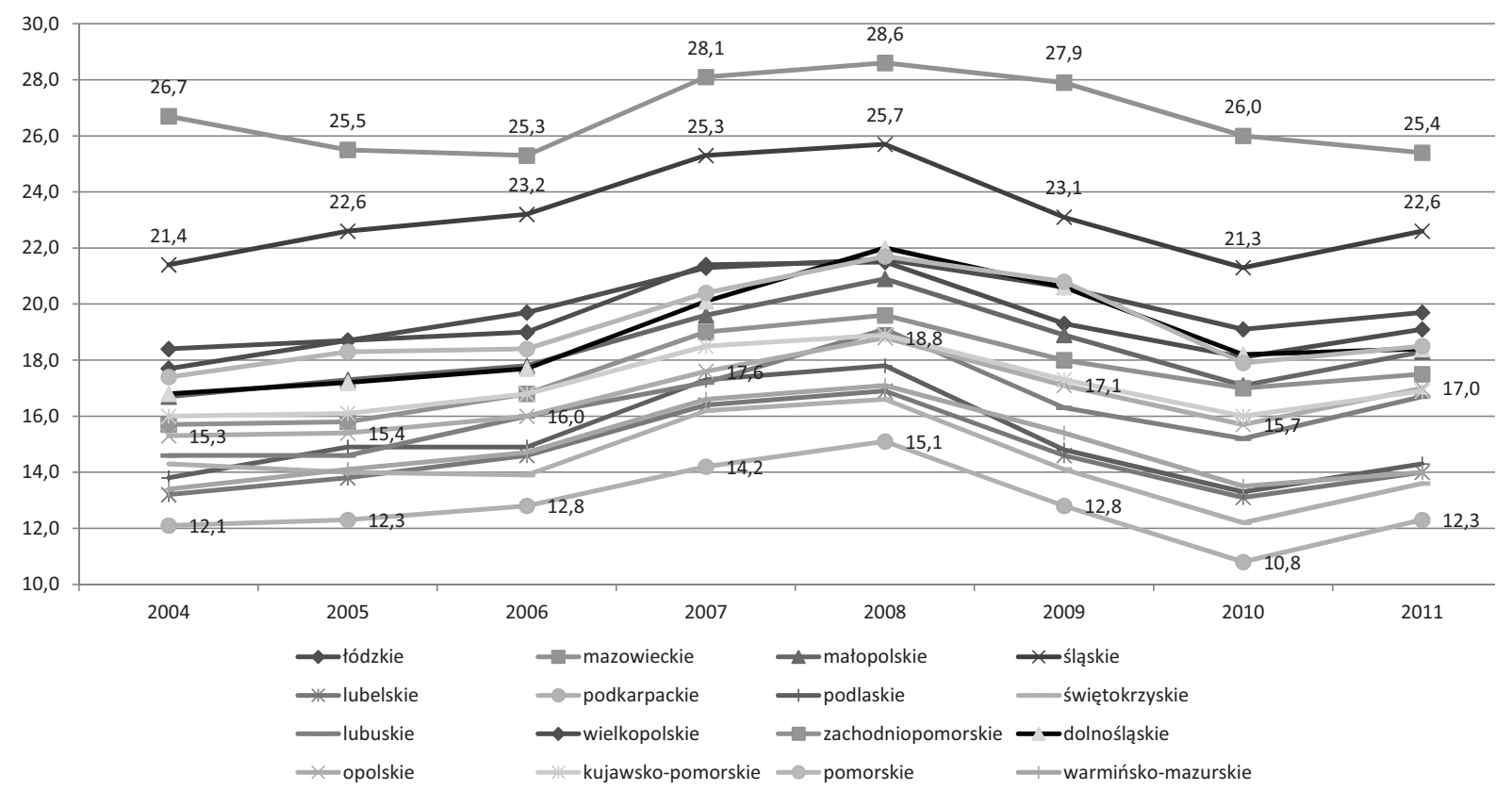

Źródło: K. Jarosiński, B. Opałka, op.cit.

W latach 2004-2011 nastąpił znaczący wzrost udziału podatku dochodowego od osób fizycznych w dochodach ogółem. W roku bazowym 2004 tylko w niewielkiej liczbie powiatów (53) udział podatku od osób fizycznych w dochodach z tytułu udziału w podatkach stanowiących dochody budżetu państwa w dochodach ogółem gmin kształtował się w przedziale od 97,0\% do 99,9\%. Największą grupę gmin, badanych pod kątem dochodów podatkowych, stanowiły gminy o wartości omawianego wskaźnika w przedziale od 90,0\% do 95,0\%. 
Rysunek 5. Udział dochodów gmin z tytułu podatku od osób fizycznych $\mathrm{w}$ dochodach gmin $\mathrm{z}$ tytułu udziału w podatkach stanowiących dochód budżetu państwa razem (w \%)

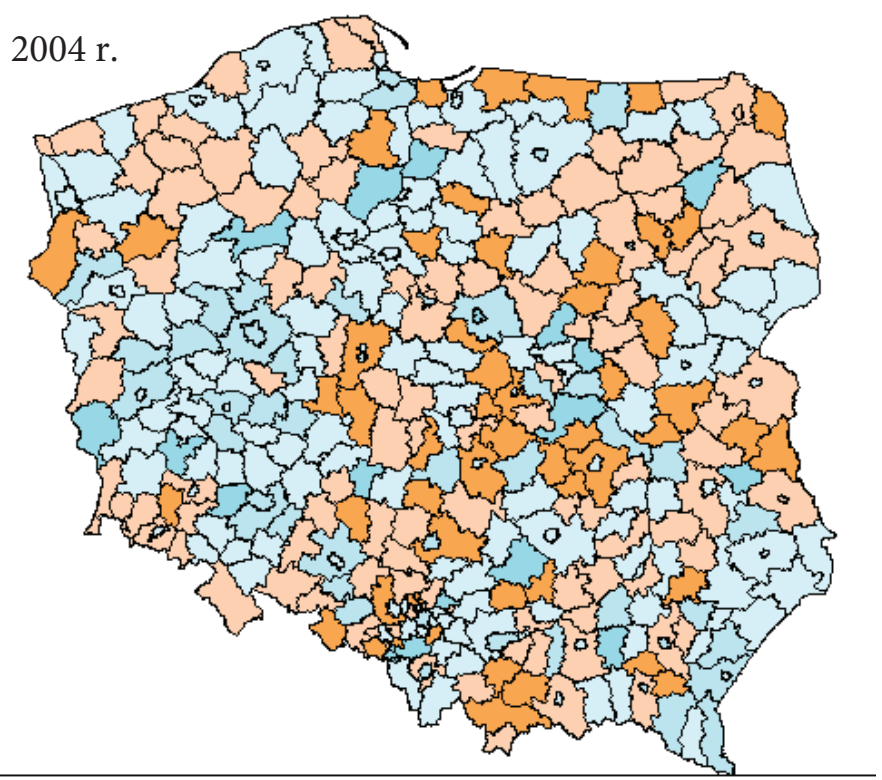

$\square 97$ do $100 \quad$ (53)
$\square 95$ do 97 (109)
$\square 90$ do 95 (152)
$\square 85$ do 90 (47)
$\square 67,8$ do 85 (18)

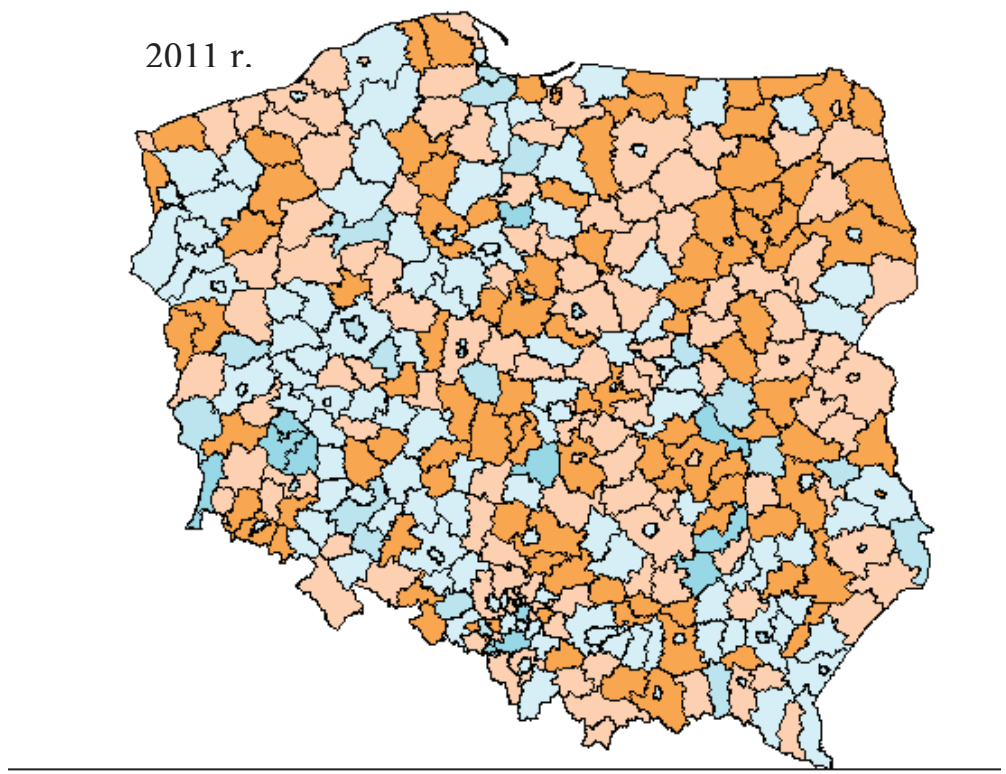

$\square 97$ do $100 \quad$ (98)

95 do $97(120)$

90 do $95(124)$

$\begin{array}{lll}85 \text { do } & 90 & \text { (25) } \\ 40 \text { do } & 85 & \text { (12) }\end{array}$

Źródło: K. Jarosiński, B. Opałka, op.cit. 
W ostatnim roku uwzględnionym w analizie (2011) w przedziale wartości wskaźnika 90,0-95,0\% odnotowano 124 powiatowe jednostki samorządu terytorialnego, w których objęto badaniem dochody budżetowe gmin. W latach 2004-2011 nastąpiło znaczące przesunięcie pewnej części jednostek samorządu terytorialnego do wyższych przedziałów wartości wskaźnika. Wzrost dochodów podatkowych gmin z tytułu udziału w podatku odchodowym od osób fizycznych stanowiącym dochody budżetu państwa znaczący sposób poprawił sytuację dochodową gmin i ją utrwalił. $\mathrm{W}$ rezultacie w miarę upływu czasu rozwiązania systemowe doprowadziły do zachowania na terenie gmin większej części wypracowanych dochodów.

\section{Rysunek 6. Dochody budżetów gmin z tytułu udziału w podatku dochodowym od osób prawnych w układzie regionalnym (w tys. zł)}

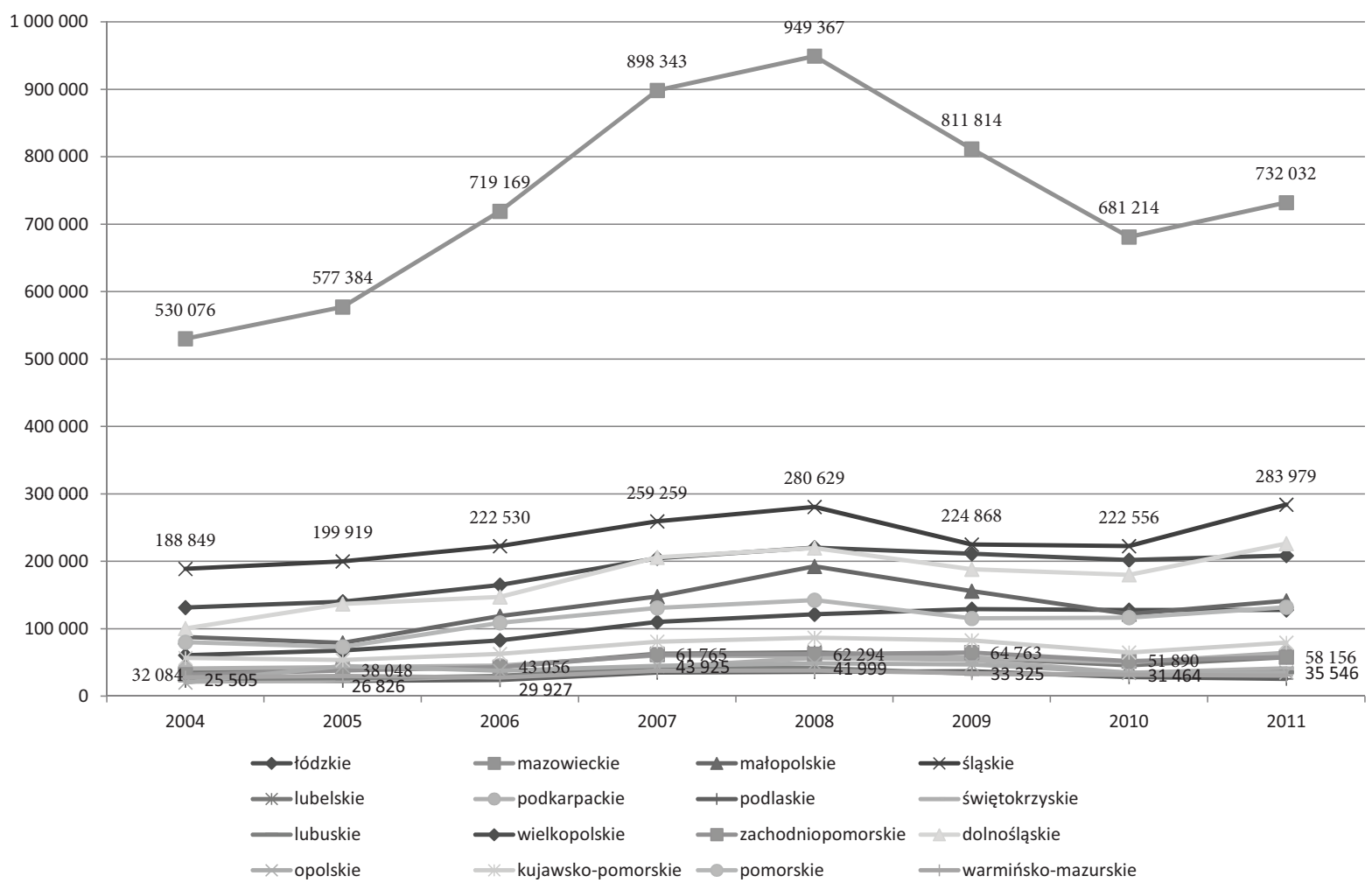

Źródło: K. Jarosiński, B. Opałka, op.cit.

Jak wynika z materiału empirycznego, dochody gmin z tytułu udziału w podatku dochodowym od osób prawnych nie stanowią zbyt istotnej wielkości w strukturze dochodów budżetowych gmin. Przyczyny takiego zjawiska są dość złożone i odnoszą się bezpośrednio do warunków gospodarowania przedsiębiorstw. Zysk nie stanowi dla przedsiębiorstwa najważniejszego kryterium oceny ich działalności i z tego powodu, nawet przy stosunkowo wysokich przychodach przedsiębiorstw, rentowność i co za tym idzie - wolumen podatku dochodowego mogą być stosunkowo niskie. 
Zmiany w podejściu do kryteriów oceny działalności przedsiębiorstwa sprawiają, że tradycyjne mierniki oceny działalności zastępowane są nowymi, jak choćby mierniki wartości przedsiębiorstwa. Taka tendencja nie jest na świecie zjawiskiem nowym, wiąże się bowiem $\mathrm{z}$ chęcią zatrzymania $\mathrm{w}$ przedsiębiorstwie możliwie największej części wypracowanej nadwyżki z jednoczesnym ograniczeniem zobowiązań o charakterze podatkowym. W Polsce w układzie przestrzennym regionów obserwuje się wyraźne zróżnicowanie rozmieszczenia funkcji gospodarczych. Pochodną takiego rozmieszczenia działalności gospodarczej są odnotowane w gminach dochody z tytułu wymienionego wyżej podatku.

Tabela 4. Dochody budżetów gmin z tytułu udziału w podatku dochodowym od osób prawnych w układzie regionalnym (w tys. zl)

\begin{tabular}{|l|c|c|c|c|c|c|c|c|}
\hline Wyszczególnienie & 2004 & 2005 & 2006 & 2007 & 2008 & 2009 & 2010 & 2011 \\
\hline Łódzkie & 60741 & 67646 & 82870 & 110052 & 121347 & 129171 & 127907 & 127953 \\
\hline Mazowieckie & 530076 & 577384 & 719169 & 898343 & 949367 & 811814 & 681214 & 732032 \\
\hline Małopolskie & 87758 & 79006 & 118781 & 147775 & 192502 & 155856 & 121908 & 141592 \\
\hline Śląskie & 188849 & 199919 & 222530 & 259259 & 280629 & 224868 & 222556 & 283979 \\
\hline Lubelskie & 35330 & 41131 & 43663 & 62932 & 65187 & 56995 & 45829 & 57574 \\
\hline Podkarpackie & 40938 & 43085 & 45430 & 60446 & 58938 & 57262 & 50075 & 64519 \\
\hline Podlaskie & 22930 & 22788 & 23867 & 34921 & 35878 & 36947 & 28203 & 25763 \\
\hline Świętokrzyskie & 21306 & 23814 & 29734 & 43073 & 56572 & 53797 & 34531 & 41363 \\
\hline Lubuskie & 25505 & 26826 & 29927 & 43925 & 41999 & 33325 & 31464 & 35546 \\
\hline Wielkopolskie & 131510 & 140053 & 165001 & 204756 & 220446 & 211290 & 201912 & 208574 \\
\hline Zachodniopomorskie & 32084 & 38048 & 43056 & 61765 & 62294 & 64763 & 51890 & 58156 \\
\hline Dolnośląskie & 100369 & 136878 & 147157 & 205939 & 219822 & 188383 & 180079 & 226245 \\
\hline Opolskie & 20257 & 44536 & 37554 & 45034 & 48802 & 46933 & 34616 & 35111 \\
\hline Kujawsko-pomorskie & 56628 & 53709 & 62617 & 80909 & 86661 & 82767 & 64770 & 79347 \\
\hline Pomorskie & 79989 & 73186 & 108844 & 130933 & 142420 & 115336 & 116566 & 131971 \\
\hline Warmińsko-mazurskie & 27893 & 29855 & 27729 & 37621 & 38039 & 34081 & 31830 & 30479 \\
\hline
\end{tabular}

Źródło: opracowanie własne na podstawie danych Banku Danych Lokalnych, op.cit.

Rezultatem przedstawionej sytuacji jest bardzo niski udział dochodów gmin z tytułu udziału w podatku dochodowym od osób prawnych w dochodach ogółem budżetów gmin. W roku 2004 udział ten w większości regionów kształtował się na poziomie od $1 \%$ do $2 \%$. Jedynie w województwach mazowieckim oraz wielkopolskim osiągał on nieco wyższy poziom i wynosił odpowiednio $4,4 \%$ oraz $2,2 \%$. W latach 2004-2011 sytuacja w tym zakresie nie uległa istotniejszym zmianom. Omawiana kategoria dochodów budżetowych gmin nadal posiada raczej marginalny charakter. Województwem o najwyższym wskaźniku w tym zakresie nadal pozostawał region mazowiecki, jednakże wartość wskaźnika w roku 2011 wynosiła już tylko 3,2\%. 
Poziom 2\% udziału przekroczony został w regionie dolnośląskim. W pozostałych regionach oscylował pomiędzy $1 \%$ a $2 \%$, z wyjątkiem województwa podlaskiego, gdzie uległ obniżeniu do poziomu $0,6 \%$. Udziały dochodów związanych z podatkiem dochodowym od osób prawnych w dochodach ogółem budżetów gmin w układzie regionalnym przedstawiono $\mathrm{w}$ tabeli 5 oraz na rysunku 7 . W omawianym okresie dochody $\mathrm{z}$ tego tytułu wyraźnie podlegały wahaniom zgodnie z ogólnymi warunkami gospodarowania oraz wpływem zjawisk kryzysowych występujących na świecie.

Tabela 5. Udzial dochodów z tytułu podatku dochodowego od osób prawnych w dochodach ogółem budżetów gmin w układzie regionalnym (w \%)

\begin{tabular}{|l|r|r|r|r|r|r|r|r|}
\hline \multicolumn{1}{|c|}{ Wyszczególnienie } & 2004 & 2005 & 2006 & 2007 & 2008 & 2009 & 2010 & 2011 \\
\hline Łódzkie & 1,3 & 1,3 & 1,5 & 1,7 & 1,7 & 1,8 & 1,7 & 1,6 \\
\hline Mazowieckie & 4,4 & 4,1 & 4,4 & 4,9 & 4,8 & 4,1 & 3,2 & 3,2 \\
\hline Małopolskie & 1,5 & 1,2 & 1,6 & 1,7 & 2,1 & 1,6 & 1,1 & 1,3 \\
\hline Śląskie & 2,0 & 1,9 & 2,0 & 2,0 & 2,0 & 1,6 & 1,5 & 1,8 \\
\hline Lubelskie & 1,0 & 1,0 & 1,0 & 1,3 & 1,2 & 1,0 & 0,7 & 0,9 \\
\hline Podkarpackie & 1,2 & 1,1 & 1,0 & 1,2 & 1,1 & 1,0 & 0,8 & 1,0 \\
\hline Podlaskie & 1,1 & 1,0 & 0,9 & 1,2 & 1,1 & 1,0 & 0,7 & 0,6 \\
\hline Świętokrzyskie & 1,0 & 1,0 & 1,1 & 1,5 & 1,8 & 1,5 & 0,8 & 1,0 \\
\hline Lubuskie & 1,4 & 1,3 & 1,3 & 1,7 & 1,6 & 1,2 & 1,0 & 1,1 \\
\hline Wielkopolskie & 2,2 & 2,0 & 2,2 & 2,3 & 2,3 & 2,2 & 2,0 & 1,9 \\
\hline Zachodniopomorskie & 1,0 & 1,0 & 1,1 & 1,4 & 1,3 & 1,3 & 1,0 & 1,0 \\
\hline Dolnośląskie & 1,7 & 2,1 & 2,0 & 2,5 & 2,6 & 2,1 & 1,8 & 2,1 \\
\hline Opolskie & 1,2 & 2,3 & 1,7 & 1,8 & 1,9 & 1,8 & 1,2 & 1,2 \\
\hline Kujawsko-pomorskie & 1,5 & 1,3 & 1,3 & 1,5 & 1,5 & 1,4 & 1,0 & 1,2 \\
\hline Pomorskie & 1,8 & 1,5 & 1,9 & 2,0 & 2,1 & 1,7 & 1,5 & 1,6 \\
\hline Warmińsko-mazurskie & 1,1 & 1,0 & 0,8 & 1,0 & 1,0 & 0,8 & 0,7 & 0,6 \\
\hline
\end{tabular}

Źródło: opracowanie własne na podstawie danych Banku Danych Lokalnych, op.cit.

O ile w układzie regionalnym wyniki analizy uległy pewnemu spłaszczeniu, o tyle analiza gmin w układzie powiatowym pozwala zauważyć, że niektóre gminy w Polsce charakteryzowały się zdecydowanie wyższym udziałem dochodów z podatku dochodowego od osób prawnych w sumie dochodów budżetów gmin wynikających z partycypacji gmin w podatkach stanowiących dochody budżetu państwa. Badając wewnętrzną strukturę tej grupy dochodów podatkowych (udziały w podatkach budżetu państwa), należy zauważyć, że pomiędzy gminami w Polsce występują daleko idące różnice w tej strukturze. 
Rysunek 7. Udział dochodów $\mathrm{z}$ tytułu podatku dochodowego od osób prawnych w dochodach ogółem budżetów gmin w układzie regionalnym (w \%)

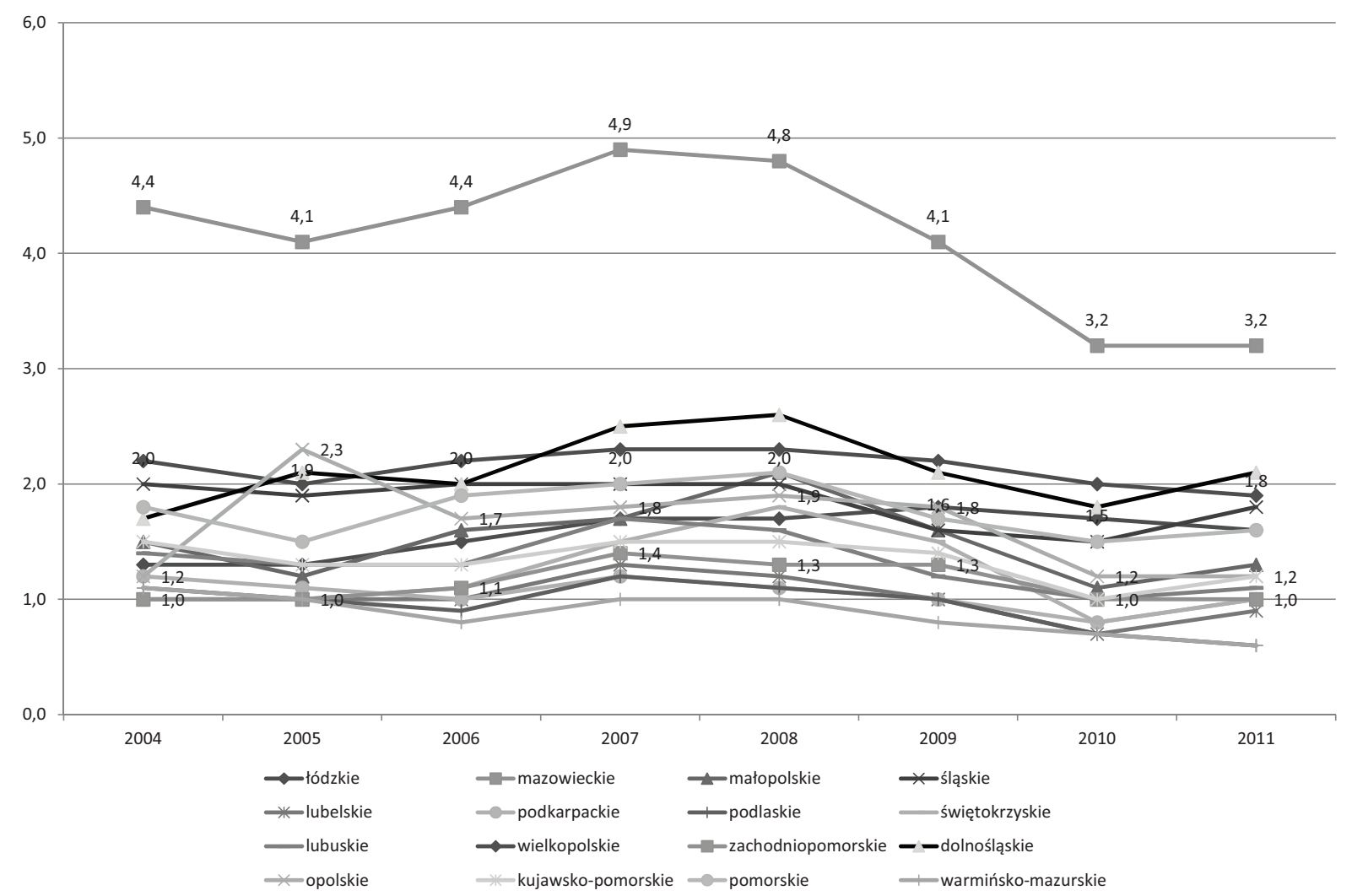

Źródło: K. Jarosiński, B. Opałka, op.cit.

Relatywnie wyższy udział występował w roku 2004 w gminach regionów małopolskiego, śląskiego, mazowieckiego, a także na terenach regionu podkarpackiego. W tym zakresie już w 2004 r. zaobserwowano występowanie znaczących różnic wewnątrzregionalnych. Zjawisko to należy uznać za normalne z uwagi na naturalną tendencję lokalizacji przedsiębiorstw w ośrodkach miejskich. Te właśnie miasta stanowiły ważne ośrodki wzrostu, które generowały relatywnie wyższe dochody podatkowe od osób prawnych. Nie należy jednak traktować powyższego stwierdzenia jako bezwzględnie obowiązującej reguły. Zgodnie z materiałem empirycznym zaobserwowano występowanie gmin o stosunkowo wysokim poziomie udziału podatku od osób prawnych w dochodach podatkowych gmin również na obszarach o zabudowie ekstensywnej i niskim poziomie zagospodarowania. Podobna sytuacja miała miejsce w roku 2011, przy czym w całej zbiorowości gmin zaobserwowano niewielki spadek udziału omawianej kategorii dochodów w sumie dochodów gmin z tytułu podatków stanowiących dochody budżetu państwa. 
Rysunek 8. Udział dochodów $\mathrm{z}$ tytułu podatku dochodowego od osób prawnych $\mathrm{w}$ dochodach gmin $\mathrm{z}$ tytułu udziału w podatkach stanowiących dochód budżetu państwa razem (w \%)

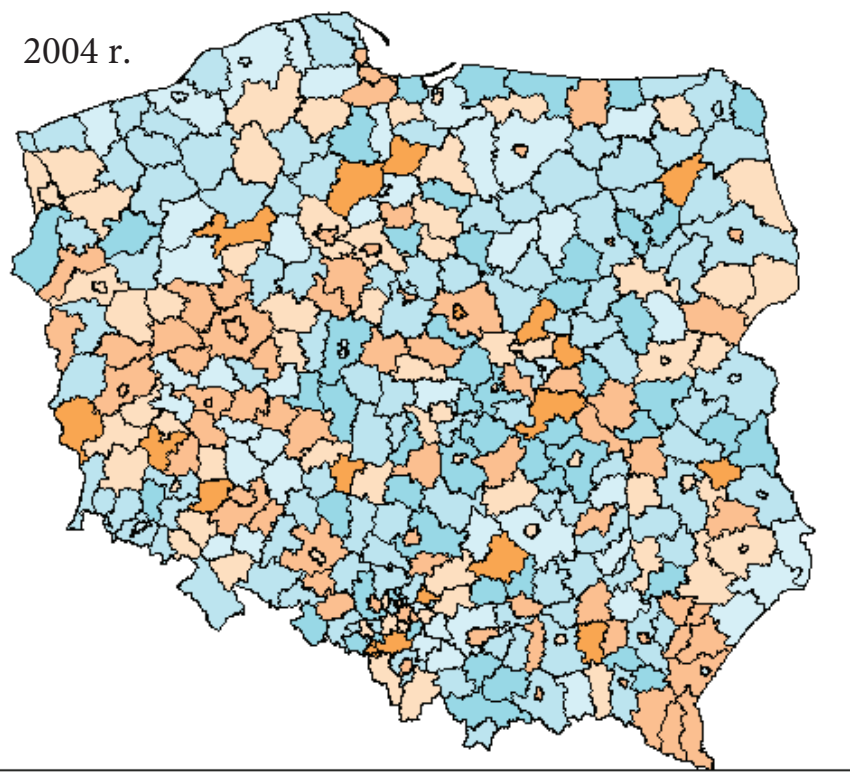

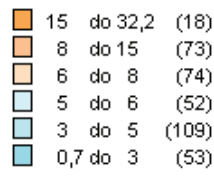

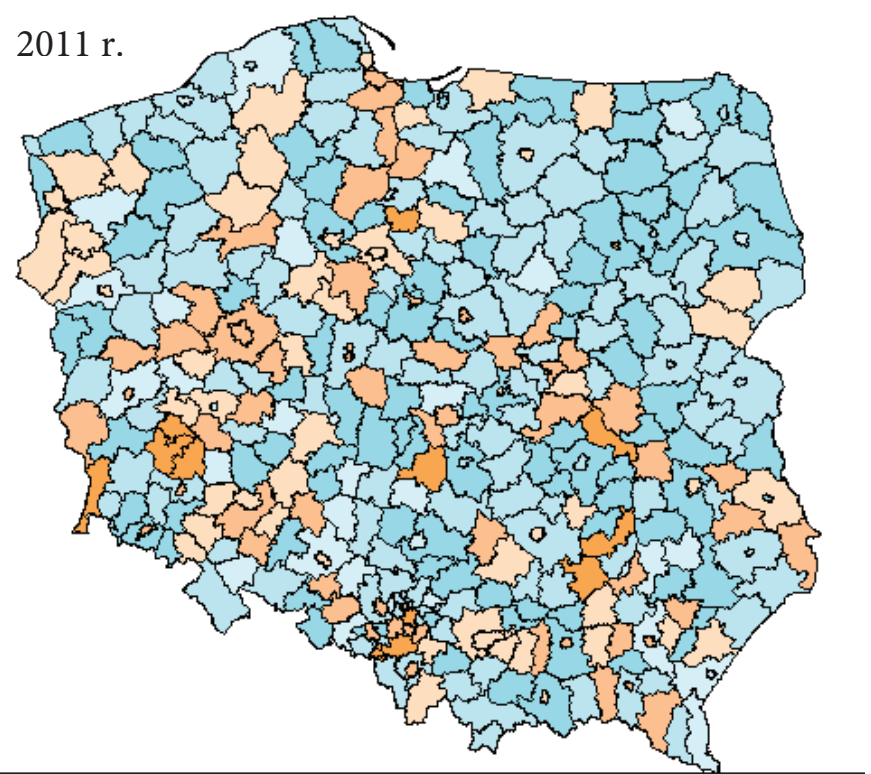

15 do 55,3 (12)

8 do $15 \quad(59)$

6 do $8 \quad(54)$

5 do 6 (36)

3 do $5 \quad(120)$

0 do $3 \quad(98)$

Źródło: K. Jarosiński, B. Opałka, op.cit. 
Tabela 6. Dochody budżetów gmin z tytułu subwencji ogółem w układzie regionalnym (w tys. zl)

\begin{tabular}{|l|r|r|r|r|c|c|c|c|}
\hline \multicolumn{1}{|c|}{ Wyszczególnienie } & \multicolumn{1}{c|}{2004} & 2005 & 2006 & 2007 & 2008 & 2009 & 2010 & 2011 \\
\hline Lódzkie & 1446350 & 1481047 & 1536379 & 1632640 & 1825422 & 1992294 & 2027890 & 2104548 \\
\hline Mazowieckie & 2952344 & 3066048 & 3267295 & 3538803 & 3928691 & 4439980 & 4591269 & 4740639 \\
\hline Małopolskie & 2212964 & 2336265 & 2495573 & 2649763 & 2939188 & 3248510 & 3431576 & 3507254 \\
\hline Śląskie & 2606391 & 2746980 & 2856234 & 3013258 & 3235129 & 3540307 & 3663509 & 3865776 \\
\hline Lubelskie & 1632887 & 1646040 & 1710504 & 1815012 & 2051861 & 2272886 & 2325453 & 2448206 \\
\hline Podkarpackie & 1593622 & 1654172 & 1748178 & 1862792 & 2051077 & 2290913 & 2420850 & 2467468 \\
\hline Podlaskie & 878943 & 903418 & 961304 & 1003884 & 1118177 & 1217970 & 1244003 & 1291711 \\
\hline Świętokrzyskie & 864584 & 893682 & 931423 & 998999 & 1112291 & 1233381 & 1279018 & 1300567 \\
\hline Lubuskie & 623935 & 632827 & 655371 & 686698 & 750205 & 822733 & 851426 & 873926 \\
\hline Wielkopolskie & 2110092 & 2156334 & 2240327 & 2360729 & 2622758 & 2900720 & 2984698 & 3108876 \\
\hline Zachodniopomorskie & 997945 & 1007695 & 1052024 & 1105790 & 1236419 & 1355533 & 1386463 & 1446401 \\
\hline Dolnośląskie & 1497327 & 1497101 & 1521997 & 1606538 & 1772363 & 1936805 & 2030030 & 2094557 \\
\hline Opolskie & 573784 & 595241 & 641585 & 682216 & 747878 & 832052 & 843691 & 866454 \\
\hline Kujawsko-pomorskie & 1390130 & 1413938 & 1490744 & 1580267 & 1764193 & 1947451 & 2016681 & 2085081 \\
\hline Pomorskie & 1348048 & 1388788 & 1451890 & 1557364 & 1737551 & 1922406 & 2017273 & 2123214 \\
\hline Warmińsko-mazurskie & 954518 & 986223 & 1043344 & 1097771 & 1221852 & 1337690 & 1365815 & 1426061 \\
\hline
\end{tabular}

Źródło: Bank Danych Lokalnych, Warszawa 2012.

\section{Rysunek 9. Dochody budżetów gmin z tytułu subwencji ogółem w układzie regionalnym} (w tys. zl)

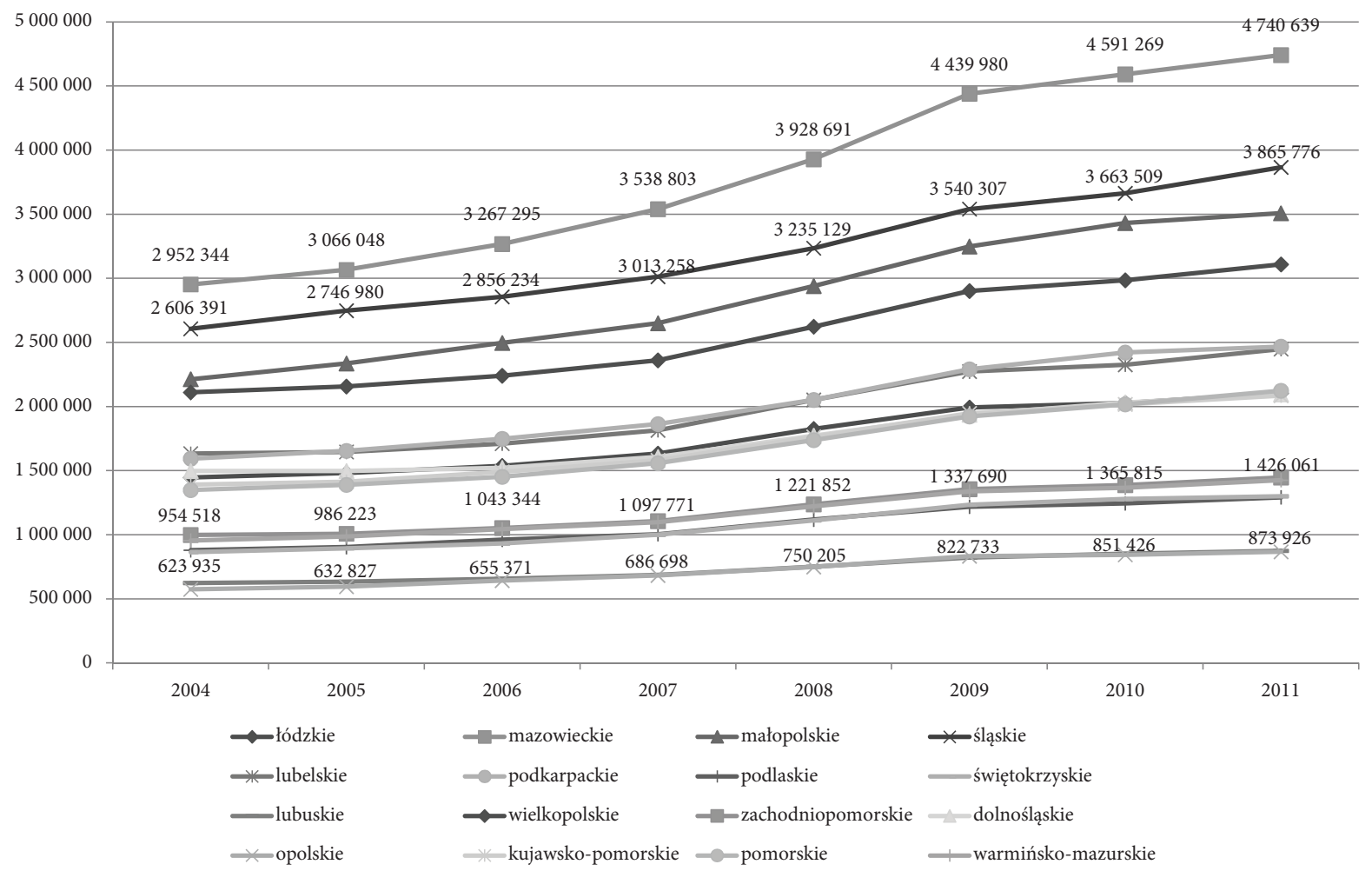

Źródło: K. Jarosiński, B. Opałka, op.cit. 
Kolejną kategorią dochodów, która w strukturze dochodów ogółem gmin odgrywa istotną rolę, jest subwencja ogólna. Subwencja ogólna składa się z kilku strumieni pieniężnych. Zgodnie z regulacjami prawnymi w skład subwencji ogólnej wchodzą następujące części: oświatowa, wyrównawcza i równoważąca. Najważniejsza z nich jest część oświatowa. W roku 2004 przykładowo w regionie śląskim subwencja oświatowa stanowiła $94,7 \%$ wartości subwencji ogółem. W tym samym czasie w regionie łódzkim wartość subwencji oświatowej stanowiła $84,8 \%$, a w regionie podlaskim - 82,2\%. W roku 2011 udział subwencji oświatowej w subwencji ogólnej w regionie łódzkim kształtował się na poziomie 79,5\%, w regionie śląskim $-88,1 \%$, zaś w województwie podlaskim - 75,9\%. Mechanizm zasilania budżetów gmin w oparciu o system subwencjonowania ma na celu zapewnienie stabilnych źródeł finansowania zadań oświatowych i wyeliminowania możliwych sytuacji niezrealizowania części zadań. W praktyce mechanizm subwencjonowania nie zawsze spełniał swoje zadanie, co skutkowało koniecznością przekazywania części środków budżetowych gmin na dofinansowania zadań o charakterze oświatowym. Szczegółowe dane charakteryzujące przepływy pieniężne z tytułu subwencji ogólnej w gminach w układzie regionalnym przedstawiono w tabeli 6 oraz na rysunku 9, a z tytułu subwencji oświatowej - w tabeli 7 oraz na rysunku 10.

Tabela 7. Dochody budżetów gmin z tytułu subwencji oświatowej w układzie regionalnym ( $w$ tys. $z$ )

\begin{tabular}{|l|r|r|r|r|r|r|}
\hline \multicolumn{1}{|c|}{ Wyszczególnienie } & \multicolumn{1}{c|}{2006} & \multicolumn{1}{c|}{2007} & \multicolumn{1}{c|}{2008} & \multicolumn{1}{c|}{2009} & \multicolumn{1}{c|}{2010} & \multicolumn{1}{c|}{2011} \\
\hline Łódzkie & 1226517 & 1301907 & 1433192 & 1528145 & 1594018 & 1672598 \\
\hline Mazowieckie & 2670815 & 2845679 & 3132213 & 3407190 & 3613290 & 3846889 \\
\hline Małopolskie & 1981397 & 2090860 & 2296566 & 2485984 & 2623195 & 2734946 \\
\hline Śląskie & 2470262 & 2612612 & 2869726 & 3074584 & 3212050 & 3403877 \\
\hline Lubelskie & 1257995 & 1315212 & 1456011 & 1562286 & 1635745 & 1727263 \\
\hline Podkarpackie & 1280918 & 1351757 & 1486418 & 1598828 & 1688901 & 1749335 \\
\hline Podlaskie & 722365 & 751033 & 823801 & 890730 & 925871 & 981264 \\
\hline Świętokrzyskie & 684119 & 726803 & 796528 & 859282 & 905911 & 942779 \\
\hline Lubuskie & 531483 & 554698 & 604659 & 647657 & 680430 & 709420 \\
\hline Wielkopolskie & 1850896 & 1937323 & 2137020 & 2311109 & 2408858 & 2539860 \\
\hline Zachodniopomorskie & 850201 & 890672 & 983675 & 1059524 & 1101815 & 1164121 \\
\hline Dolnośląskie & 1284312 & 1333203 & 1451150 & 1567512 & 1641711 & 1722796 \\
\hline Opolskie & 513377 & 538968 & 584807 & 627794 & 659909 & 694283 \\
\hline Kujawsko-pomorskie & 1199180 & 1263289 & 1392337 & 1502820 & 1574490 & 1663665 \\
\hline Pomorskie & 1221260 & 1292069 & 1446261 & 1581065 & 1676699 & 1795077 \\
\hline Warmińsko-mazurskie & 800549 & 845098 & 923413 & 983170 & 1020780 & 1080037 \\
\hline
\end{tabular}

Źródło: opracowanie własne na podstawie danych Banku Danych Lokalnych, op.cit. 


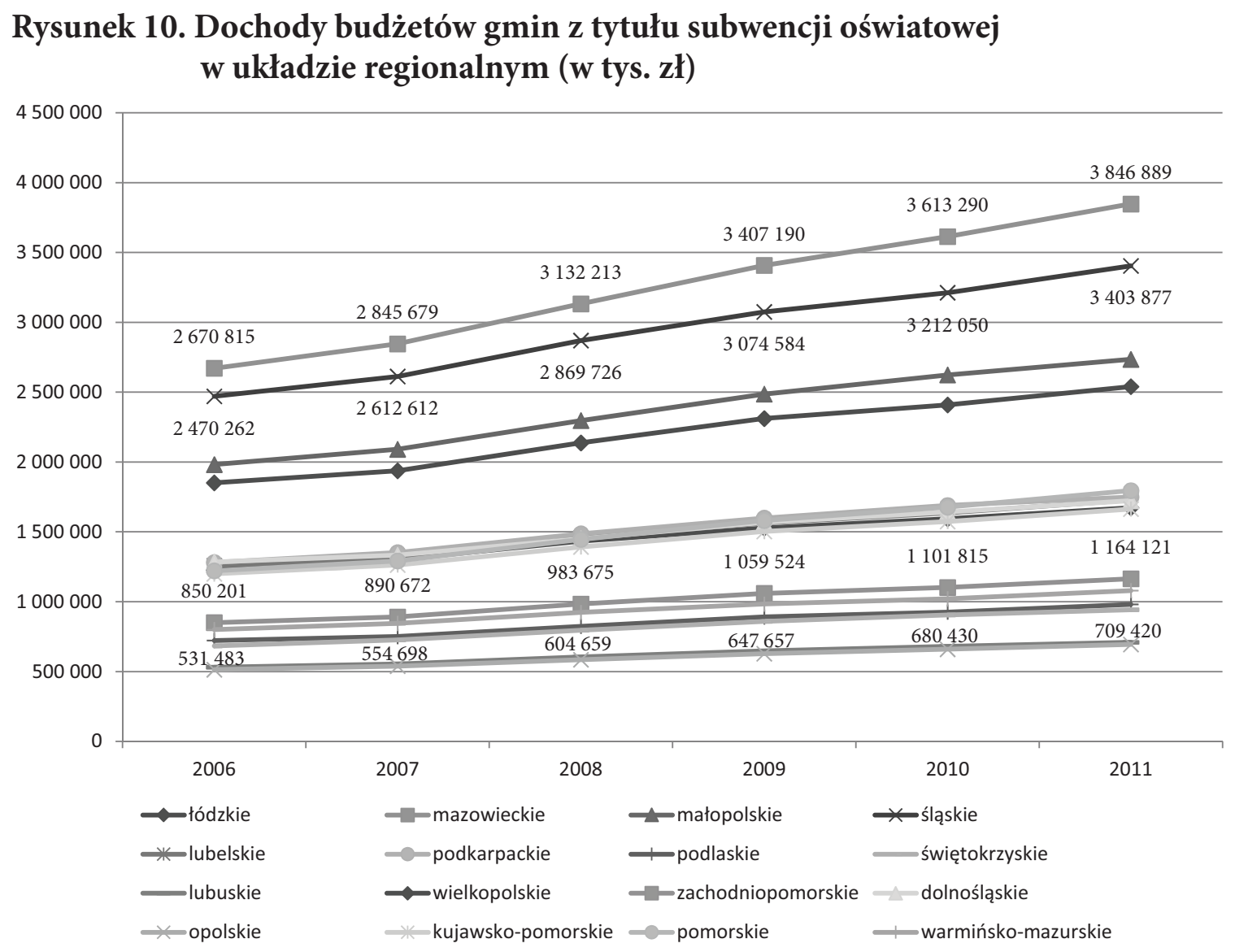

Źródło: opracowanie własne na podstawie danych Banku Danych Lokalnych, op.cit.

Po przystąpieniu Polski do Unii Europejskiej jednym z ważniejszych źródeł dochodów budżetów gmin stały się środki przekazywane w ramach polityki spójności UE. W szczególności należy zwrócić tu uwagę na środki przekazywane w ramach Europejskiego Funduszu Rozwoju Regionalnego, Europejskiego Funduszu Społecznego i Funduszu Spójności. Środki budżetowe UE są ważnym źródłem wspierania rozwoju społeczno-gospodarczego w Polsce na poziomie lokalnym. Na skutek łączenia środków unijnych oraz własnych odnotowano w badanym okresie wzrost stopy inwestycji w gminach. W przeważającej części inwestycje realizowane były w sferze infrastruktury społecznej oraz technicznej, co wyraźnie przyczyniło się do zmniejszenia luki infrastrukturalnej w Polsce. W trakcie badania zgromadzono dane liczbowe oraz podjęto analizę dochodów gmin związanych z realizacją projektów współfinansowanych ze środków UE. Wobec ograniczonej ciągłości danych w badaniu podjęto analizę obejmującą tylko lata 2010 oraz 2011.

Istotny walor poznawczy w aspekcie wpływu środków pochodzących z budżetu Unii Europejskiej na wspieranie procesów rozwoju społeczno-gospodarczego posiada analiza rzeczywistego wkładu tych środków w stosunku do dochodów i wydatków ogółem. W badaniu na potrzeby analizy wyodrębnione zostały dochody budżetowe 
gmin wpływające $z$ tytułu finansowania i współfinansowania programów i projektów unijnych, z wyłączeniem środków pochodzących ze źródeł krajowych. Istotne zatem było zbadanie, w jakim stopniu środki unijne przyczyniały się do współfinansowania zadań publicznych.

W gminnych jednostkach samorządu terytorialnego wykorzystanie środków unijnych na realizację zadań publicznych cechowało się istotnym zróżnicowaniem. W układzie regionalnym w roku 2010 wartościowo najwięcej środków przekazano gminom na terenie województwa mazowieckiego, a także śląskiego i małopolskiego. W ujęciu bezwzględnym stosunkowo niski poziom dofinansowania zanotowano w województwach zachodniopomorskim, opolskim oraz lubuskim. Szczególną pozycję po względem wykorzystania wsparcia w ramach funduszy strukturalnych zajmowało oraz zajmuje województwo mazowieckie. Dotyczy to zarówno poziomu przekazanego wsparcia, jak i najwyższej dynamiki wzrostu. Wyróżniającą się dynamikę, choć już nieco niższą, zaobserwowano w regionach śląskim i małopolskim. Również dość wysoką dynamikę zmian odnotowano w gminach zagregowanych dla województwa wielkopolskiego. W omawianej kategorii dochodów odnotowano tam wzrost na poziomie 79,9\%.

Tabela 8. Dochody budżetów gmin pozyskane $\mathrm{z}$ tytułu finansowania i współfinansowania programów i projektów unijnych (bez środków krajowych) w układzie regionalnym (w tys. zł)

\begin{tabular}{|l|c|c|}
\hline \multicolumn{1}{|c|}{ Wyszczególnienie } & 2010 & 2011 \\
\hline Łódzkie & 610076,8 & 444796,9 \\
\hline Mazowieckie & 994221,2 & 1473347,7 \\
\hline Małopolskie & 674288,7 & 814317,5 \\
\hline Śląskie & 987531,2 & 1101767,4 \\
\hline Lubelskie & 495110,0 & 672576,4 \\
\hline Podkarpackie & 595433,9 & 695708,2 \\
\hline Podlaskie & 431720,1 & 455170,2 \\
\hline Świętokrzyskie & 425692,1 & 485785,2 \\
\hline Lubuskie & 248139,9 & 199830,0 \\
\hline Wielkopolskie & 296297,5 & 533172,3 \\
\hline Zachodniopomorskie & 175716,0 & 334125,3 \\
\hline Dolnośląskie & 550130,2 & 758633,0 \\
\hline Opolskie & 181173,0 & 185758,1 \\
\hline Kujawsko-pomorskie & 332282,2 & 436947,9 \\
\hline Pomorskie & 389284,5 & 617727,9 \\
\hline Warmińsko-mazurskie & 398112,6 & 523780,0 \\
\hline
\end{tabular}

Źródło: opracowanie własne na podstawie danych Banku Danych Lokalnych, op.cit. 
W roku 2011 w odniesieniu do większości regionów zaobserwowano wzrost wysokości dochodów budżetowych wobec finansowania i współfinansowania programów i projektów unijnych. Szczególną sytuację odnotowano w województwie łódzkim. Przy stosunkowo wysokim poziomie dochodów unijnych w roku 2010 miał miejsce spadek tej kategorii dochodów o 27,1\% w 2011 r. Spadek dochodów odnotowano również $\mathrm{w}$ województwie lubuskim. Jednoznaczna ocena przyczyn takich różnokierunkowych zmian jest utrudniona z uwagi na specyfikę warunków pozyskiwania wsparcia w ramach środków unijnych przez poszczególne gminy w zależności od uwarunkowań regionalnych, co w rezultacie wymagałoby szczegółowego przeanalizowania w ujęciu obszaru każdego z województw. Graficzną ilustrację zmian dochodów budżetów gmin w powyższej kategorii zaprezentowano na rysunku 11 .

\section{Rysunek 11. Dochody budżetów gmin pozyskane z tytułu finansowania i współfinansowania programów i projektów unijnych (bez środków krajowych) w układzie regionalnym (w tys. zł)}

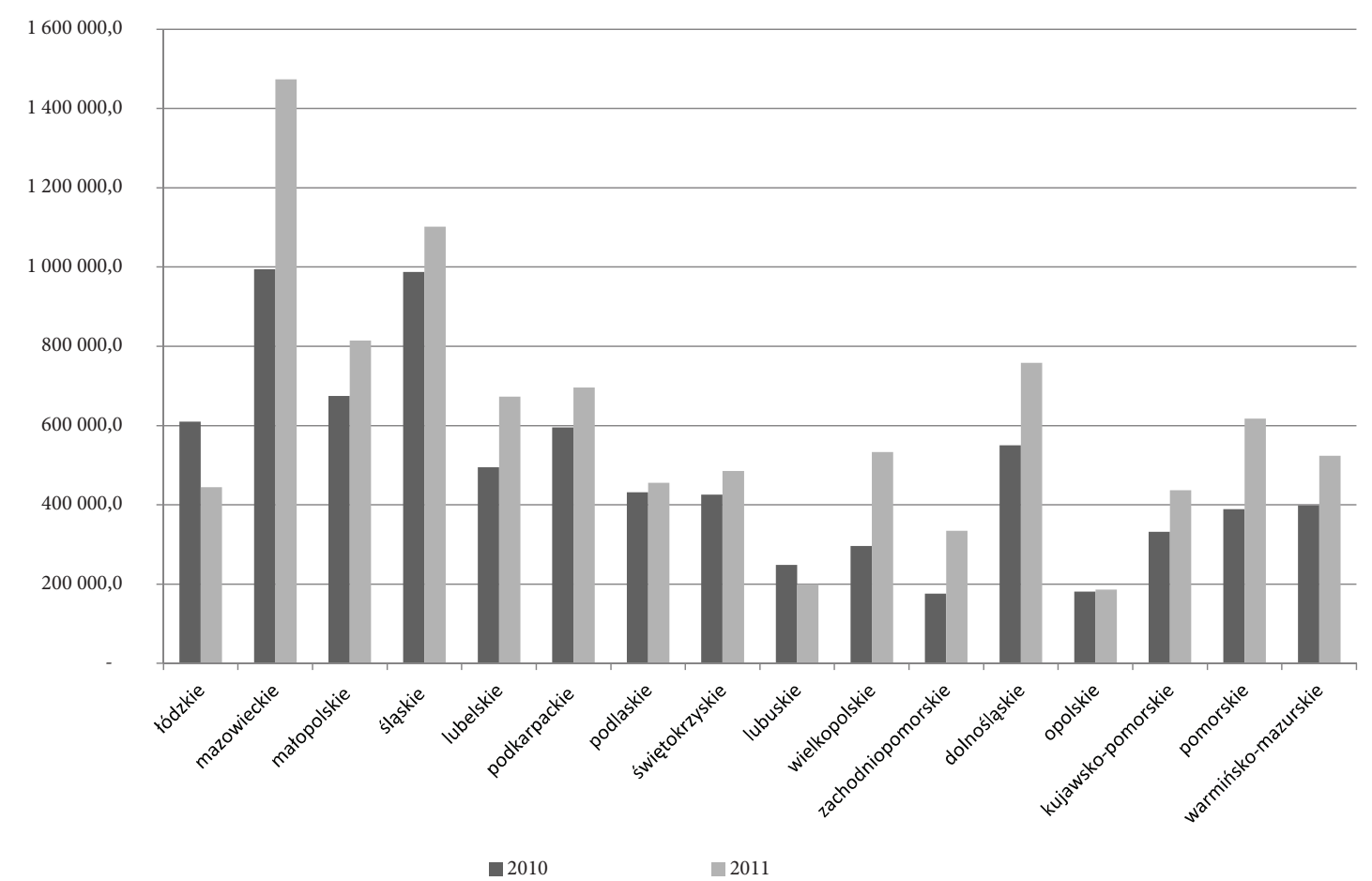

Źródło: K. Jarosiński, B. Opałka, op.cit.

Na rysunku 12 zilustrowano sytuację w zakresie dochodów gmin z tytułu finansowania i współfinansowania programów i projektów unijnych w układzie powiatowym w 2011 r. Interesującym zjawiskiem jest koncentracja dochodów na obszarach powiatów zlokalizowanych na południu Polski, a także w części środkowowschodniej i północnej. Stosunkowo niski poziom dochodów w tej kategorii zaobserwowano 
głównie na obszarach powiatów zachodniej części Polski. Podobną sytuację zaobserwowano również $\mathrm{w}$ gminach zlokalizowanych na terenach powiatów Polski północno-wschodniej.

Należy zaznaczyć, że na terenie Polski ogólnie odnotowano bardzo wysokie zróżnicowanie omawianych dochodów. Występowało ono w gminach w układzie powiatowym szczególnie w Polsce centralnej. Odrębne miejsce, jak już wspomniano, zajmowało m.st. Warszawa. Ponadto dość specyficzna sytuacja występowała w gminach znajdujących się w strefie metropolitalnej Warszawy. Na tych terenach nie odnotowano szczególnie wysokiego poziomu dochodów budżetowych z omawianej kategorii.

\section{Rysunek 12. Dochody budżetów gmin pozyskane z tytułu finansowania i współfinansowania programów i projektów unijnych (bez środków krajowych) w układzie powiatowym w 2011 r. (w zl)}

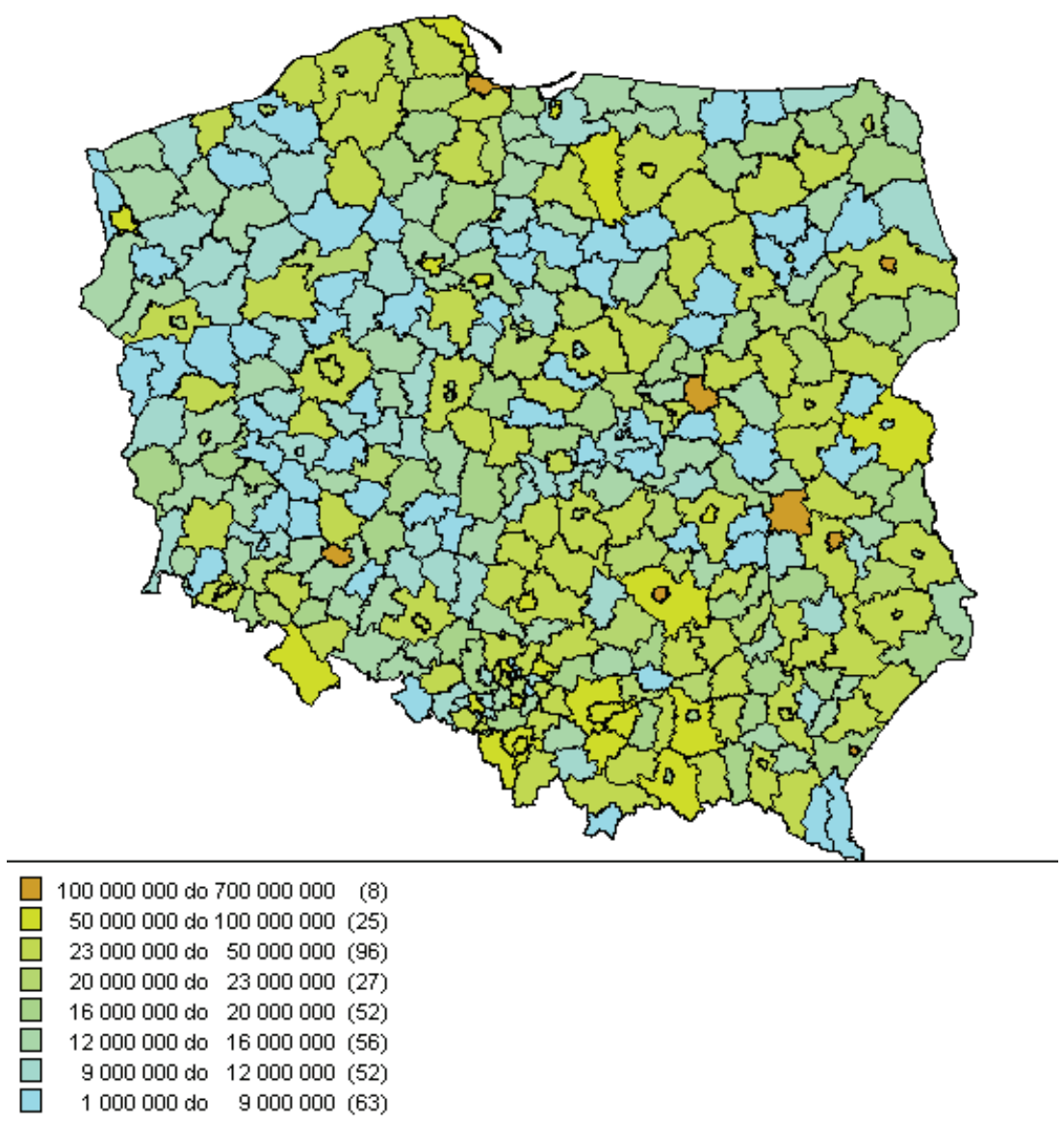

Źródło: K. Jarosiński, B. Opałka, op.cit. 


\section{Wnioski}

Na podstawie przeprowadzonych badań należy stwierdzić, że analizowane kategorie dochodów przekazywanych budżetom gminnym z budżetu państwa nadal odgrywają ważną rolę w strukturze dochodów budżetowych gmin. Jako szczególnie istotny należy oceniać wzrost dochodów gmin z tytułu udziału w podatkach dochodowych stanowiących dochody budżetu państwa (głównie podatku dochodowego od osób fizycznych), który w znaczący sposób poprawił sytuację budżetową gmin po stronie dochodowej, a nawet ją utrwalił poprzez zagwarantowanie określonego zasobu finansowego, powiązanego z potencjałem gospodarczym, zasilającego budżety gminne. Wynika to w znacznej mierze $\mathrm{z}$ wprowadzanych rozwiązań systemowych w Polsce, które zmierzały do zatrzymania w gminach większej części wypracowanych dochodów sferze gospodarki realnej. Jak wskazują badania prowadzone w ujęciu przestrzennym, w rezultacie w latach 2004-2011 odnotowano wyraźne przemieszczenie pewnej części jednostek samorządu terytorialnego do wyższych przedziałów wartości wskaźników udziału dochodów związanych z podatkami dochodowymi w dochodach budżetowych ogółem.

Jak wynika $z$ danych liczbowych oraz prowadzonych badań, Polska należy do grupy krajów, w których wolumen wsparcia przekazywanego z budżetu UE jest relatywnie wysoki. Z jednej strony oznacza to ogromną szansę prorozwojową, jednakże pełne wykorzystanie zarysowanych możliwości okazuje się trudniejsze, niż wynikałoby to z analiz odnoszących się do sposobów wykorzystania zasobów unijnych. Wspomniane wsparcie co do zasady należy uznać za korzystny mechanizm umożliwiający bezkosztowe wprowadzenie kapitału o charakterze bezzwrotnym do zróżnicowanych przedsięwzięć, w tym także projektów inwestycyjnych w jednostkach samorządu terytorialnego. W praktyce oznaczało to zwiększenie wolumenu inwestycji, w szczególności jeśli chodzi o zmniejszenie luki infrastrukturalnej, stanowiącej dobrze rozpoznaną i wyraźnie widoczna barierę rozwojową.

Należy podkreślić, że w gminach na terenie Polski odnotowano bardzo wysokie zróżnicowanie dochodów z tytułu dofinansowania projektów oraz programów współfinansowanych w ramach środków unijnych, w tym szczególnie widoczne było ono w gminach w układzie powiatowym w Polsce centralnej. Odrębnej ocenie należy poddać m.st. Warszawa, w którym zróżnicowanie funkcji lokalnych, regionalnych oraz krajowych sprawiło, że sytuacja dochodowa była zdecydowanie lepsza niż w pozostałych jednostkach samorządu terytorialnego w Polsce. Specyficzna sytuacja miała miejsce również w gminach strefy metropolitalnej Warszawy, gdzie 
poziom dochodów budżetowych z omawianej kategorii nie był aż tak wysoki, jak można by się spodziewać.

Należy wskazać, że zjawiska kryzysowe na świecie, procesy integracyjne w Europie, a także trudności finansowe związane z nadmiernym długiem publicznym w strefie euro nakazują zachować dużą ostrożność przy ocenie możliwych dalszych scenariuszy rozwoju. Zgodnie z założeniami polityki spójności dochody budżetów jednostek samorządu terytorialnego powinny charakteryzować się wzrostem w kolejnym okresie programowania. Do takiej konkluzji skłaniają wyniki badań oraz sytuacja społeczno-gospodarcza w Polsce. Wobec zjawisk kryzysowych mających zasięg globalny, a które dosięgają również w coraz większym stopniu Polskę, można jednak mieć obawy, czy przyszły kształt budżetu UE i zakres wsparcia na rzecz rozwoju będą dotrzymane zgodnie z oczekiwaniami.

\section{Słowa kluczowe:}

finanse publiczne, rozwój regionalny, budżet

\section{Keywords:}

public finance, regional development, budget

\section{Selected budgetary income of gminas transferred from national budget in Poland in spatial perspective (2004-2011)}

After Poland's accession to EU regional and local development as well as public administration actions for improvement of conditions of living were tied with the necessity to invest heavily, especially in infrastructure. Providing necessary funds meant combining funds from different sources, particularly from public resources and from the EU budget.

In the present system of financing the tasks of local government, external income, transferred to the local government through national budget, is important part of development policy, even though it limits financial self-reliance of local government.

Income transferred to gminas from national budget, especially the gminas' share of personal income tax, still plays important part in their budgets. 
The amount of money transferred to gminas to co-finance with EU different projects and programs shows large spatial differences which influences the level of investments, especially in infrastructure.

\section{Les recettes fiscales des communes provenant du budget de l'État en termes géographiques en Pologne dans les années 2004-2011}

Après l’adhésion de la Pologne à l'UE, le développement régional et local ainsi que les actions de l'administration publique afin d'améliorer les conditions de vie des habitants étaient associés à la nécessité d’engager des dépenses importantes, notamment dans les infrastructures. Pour assurer un financement adéquat des investissements, il était nécessaire de combiner les moyens provenant de différentes sources, en particulier des ressources propres et des ressources de l'UE. Dans l'évaluation du gouvernement local concernant l'importance des différentes sources de revenus du budget, c'est la liberté en terme de la collection de recettes fiscales qui reste significative. Cependant, il faut également faire attention aux dépenses. Dans le système actuel de financement des tâches de l'administration publique locale, les recettes externes, transférées aux collectivités locales à travers le budget de l'État, constituent une dimension importante de la politique de développement, en dépit de leur caractère restrictif en terme de l'indépendance financière de ces collectivités. A la suite des études effectuées, il convient de noter que les recettes fiscales des communes provenant du budget de l'État continuent de jouer un rôle important dans la structure des recettes municipales. Ce sont les recettes provenant des impôts sur le revenu, y compris sur les individus, qui sont d'une importance particulière. Une observation intéressante dans le cas des communes polonaises montre une très grande hétérogénéité spatiale des recettes provenant de projets et programmes cofinancés par les fonds de l'UE. Cette diversité détermine le niveau des investissements, en particulier ceux qui visent à réduire le déficit d'infrastructure. Depuis des années le déficit mentionné est un obstacle évident et significatif au développement. Lanalyse de ce phénomène et les mesures appropriées sont d'une importance particulière face à la définition d'une future structure du budget de l'UE et à la détermination de la portée du soutien de l'UE pour le développement socio-économique des États membres. 


\section{Избранные доходы муниципальных бюджетов передаванные из государственного бюджета в пространственном размещении в Польше в 2004-2011 годах}

После вступления Польши в ЕС, региональное и местное развитие, а также действия государственного управления по улучшению жилищных условий были связаны с необходимостью понести значительные капитальные затраты, в основном в инфраструктуру. Обеспечение соответствующего финансирования требовало объединения ресурсов из разных источников, в особенности из собственных средств, а также ресурсов из бюджета ЕС.

По мнению органов местного самоуправления, касающегося значения отдельных источников бюджетных доходов, существенной остается свобода в сфере образования бюджетных средств, однако надо обращать внимание также на условия их расходования. При нынешней системе финансирования задач местного самоуправления доходы передаванные единицам местного самоуправлени из государственного бюджета являются одним из важных аспектов политики развития, не смотря на их ограничительный характер по отношении к финансовой независимости этих единиц.

В результате проведенного исследования следует отметить, что доходы переданные муниципальным бюджетам из государственного бюджета по-прежнему играют важную роль в структуре доходов муниципальных бюджетов. Особенно важны - доходы гмин являющееся частью налогов на доходы физических лиц и представляющие собой доходы государственного бюджета.

Следует отметить также сверхвысокое пространственное дифференцирование доходов среди гмин в Польше по дофинансированию проектов и программ совместно финансированных из средств Европейского Союза. Вышеуказанная дифференциация обуславливает уровень капиталовложений, в частности служивших уменьшению инфраструктурного разрыва, являющегося хорошо известным барьером развития. Исследование вышеуказанного явления и принятие соответствующих мер особо важно, принимая во внимание процесс формирования будущего бюджета ЕС и устанавления рамок для поддержки общественно-экономического развития стран-членов. 